\title{
Primary adenocarcinoma of the thymus: an immunohistochemical and molecular study with review of the literature
}

\author{
Maryam Maghbool ${ }^{1}$, Mani Ramzi ${ }^{2}$, Inga Nagel ${ }^{3}$, Pablo Bejarano ${ }^{4}$, Reiner Siebert ${ }^{3}$, Abolfazl Saeedzadeh ${ }^{1}$ \\ and Yahya Daneshbod ${ }^{1 *}$
}

\begin{abstract}
Background: Primary adenocarcinoma of thymus is extremely rare.

Case presentation: This is a case of primary adenocarcinoma with intestinal differentiation and focal mucin production in the thymus. Thymic cyst was associated with this tumor. Intestinal differentiation was confirmed by immunohistochemical stain with positivity for CDX-2, CK20, villin, MOC31 and focal positivity of CK7. Array comperative genomic hybridization (CGH) analysis showed a complex pattern of chromosomal imbalances including homozygous deletion at the HLA locus in chromosomal region 6p21.32.
\end{abstract}

Conclusion: This rare tumor shows a similar genetic aberration with other studied thymic epithelial tumors.

Keywords: Thymus gland, Primary adenocarcinoma, Intestinal differentiation, Thymic carcinoma, Thymoma, Molecular study, CGH array, Immunohistochemical study, Literature review

\section{Background}

Primary thymic carcinomas are very rare tumors. The most common histologic subtypes are squamous cell, adenosquamous/mucoepidermoid, basal cell, large cell undifferentiated, adenocarcinoma, carcinoma with adenoid cystic carcinoma-like features, lymphoepitheliomalike, clear cell, and sarcomatoid carcinomas [1]. Primary thymic adenocarcinoma was first reported in 1989 [2] but has not been accepted as a valid histologic subtype until 1997 [3]. These are uncommon neoplasms. Papillary adenocarcinoma and mucinous adenocarcinoma are the most common variants [1,4-6]. Therefore, before a diagnosis of a de novo thymic adenocarcinoma, other possible diagnoses such as: metastatic carcinoma, thymoma and adenocarcinoma arising in a mediastinalteratoma should be excluded [1,7]. There is little genetic data for thymic carcinomas other than squamous cell carcinomas [8], so we applied a genetic study by array comperative genomic hybridization $(\mathrm{CGH})$ analysis on this case.

\footnotetext{
*Correspondence: y@daneshbod.com

'Department of Molecular Pathology, Dr Daneshbod Pathology Laboratory, Shiraz, Iran

Full list of author information is available at the end of the article
}

\section{Case presentation}

A 28 year old woman presented with neck and right upper extremity pain accompanied by dyspnea of two years duration. Chest $\mathrm{X}$ - ray revealed mediastinal widening (Figure 1A). Chest computed tomography (CT) scan (Figure 1B) showed an anterior mediastinal mass invading in pericardium without extramediastinal extension. An initial clinical impression of a mediastinal germ cell tumor was considered but serum tumor markers such as alpha-feto protein (AFP), Beta-human chorionic gonadotropin ( $\beta$-hCG), carcinoembryonic antigen (CEA) and CA-125 were normal. CA19-9 level was 2420 U/ml (normal: $0.37 \mathrm{U} / \mathrm{ml}$ ). A mediastinal biopsy was done and showed histologic features of adenocarcinoma. Endoscopy, colonoscopy, abdominopelvicsonography and imaging studies were negative for primary origin. The patient underwent mid-sternotomy. The mass was resected. The patient received chemotherapy (GEMOX) and radiotherapy with two recurrences in 2 years follow up. She is doing well and free of tumor after 6 months. 

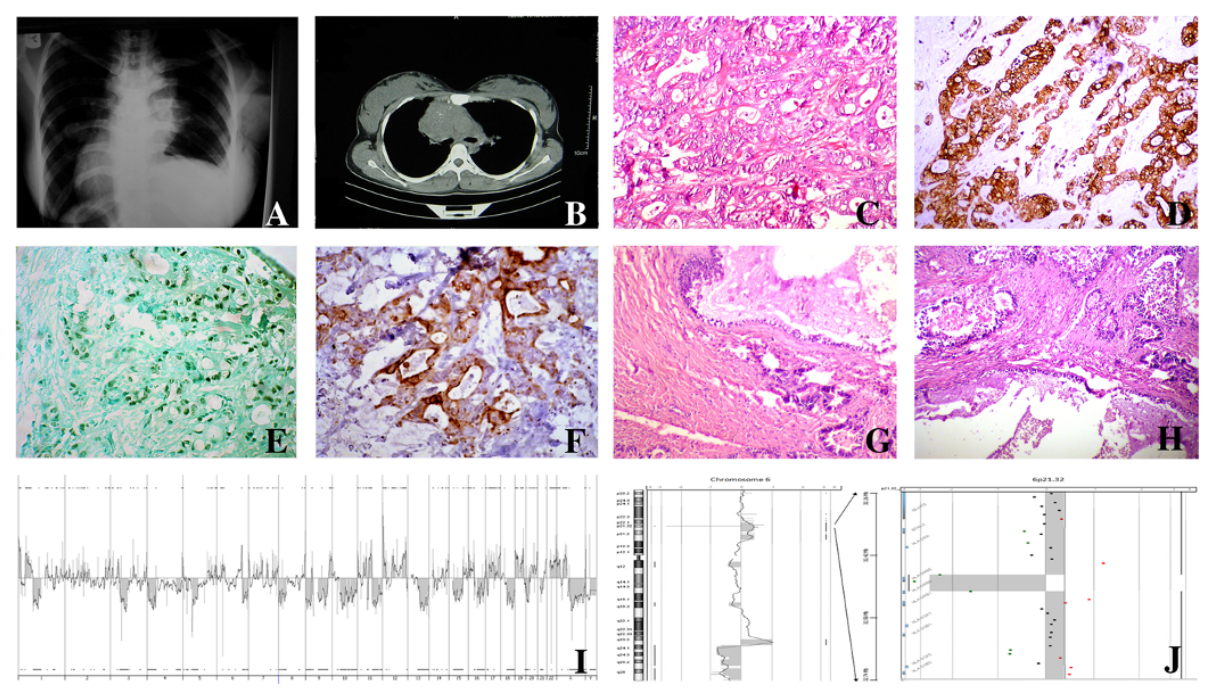

Figure 1 Representative images of radiology, histology, immunostaining as well as results of array-comparative genomic hybridization (array-CGH). A: Chest $X$ ray showed mediastinal widening. B: chest $C T$ scan revealed anterior mediastinal mass that invade pericardium. C: tumoral sheets and glandular structures in desmoplasticstroma (H\&E stain, $\times 400$ ). D: Malignant glands showed diffuse membranous positivity for CD5. (Immunoperoxidase). E: nuclear positivity for CDX-2 in malignant glands (Immunoperoxidase). F: Malignant glands showed diffuse positivity for CK20 (Immunoperoxidase). G: benign columnar linningthymic cyst adjacent to neoplastic glands (H\&E stain, $\times 200$ ). H: neoplastic glands arising in the vicinity of thymic cyst (H\&E stain, $\times 200$ ). I: Array-CGH-results displayed in a whole genome view showed deletion of chromosome 6. J: Homozygously deleted region around the HLA-DRB5-locus in chromosomal region 6p21.32.

\section{Pathologic findings}

The mediastinal biopsy showed a moderately differentiated adenocarcinoma with a desmoplastic and necrotic stroma (Figure 1C). Scattered small mucinous lakes were noted in the stroma. The stroma also showed foci of calcification and occasional psammoma bodies. Intracytoplasmic and stromal positive reactions were seen on mucicarmin stain. The excised tumor showed similar morphological and immunohistochemical characteristics. In one of the sections, a unilocunar large cyst with columnar epithelium, in vicinity of the tumor was also identified (Figure 1G, H). Small foci of remnant of thymic tissue were identified. Immunohistochemical (IHC) study showed positivity for CK, EMA, CK20 (Figure 1D), CDX-2 (Figure 1E), CK7, CD5 (Figure 1F), villin, HMWK(focal) and MOC31 but ER, PR, TTF-1, GCDFP-15, P63, CD30, PLAP, chromogranin, calretinin and CD117 were all negative. Commercial sources, clones, and working dilutions of antibodies used in the study are listed in Table 1. Extensive histologic and immunohistochemical study of the whole specimen showed no evidence of teratomatous or germ cell elements.

\section{Genetic abberations in formalin-fixed paraffin-embedded tissue}

Array $\mathrm{CGH}$ on this case was performed using the Human Genome Microarray 180A platform (Agilent, Santa Clara, USA). The experimental procedures were performed according to the protocols provided by the
Table 1 Comercial sources, clones, and working dilutions of antibodies used in this case

\begin{tabular}{cccl}
\hline Antibody & Dilution & Clone & \multicolumn{1}{c}{ Vendor } \\
\hline HMWK & Ready to use & 34 BE12 & Novocastra, New Castle, UK \\
EMA & Ready to use & GP1.4 & Novocastra, New Castle, UK \\
CK & Ready to use & AE1/AE3 & Novocastra, New Castle, UK \\
CK20 & Ready to use & PW31 & Novocastra, New Castle, UK \\
CDX-2 & 1: 100 & AMT28 & Novocastra, New Castle, UK \\
CK7 & Ready to use & RN7 & Novocastra, New Castle, UK \\
CD5 & Ready to use & 4C7 & Novocastra, New Castle, UK \\
Villin & $1: 200$ & CWWB1 & Novocastra, New Castle, UK \\
MOC31 & 1:50 & MOC31 & Novocastra, New Castle, UK \\
ER & Ready to use & 6 F11 & Novocastra, New Castle, UK \\
PR & Ready to use & 16 & Novocastra, New Castle, UK \\
TTF-1 & $1: 200$ & SPT24 & Novocastra, New Castle, UK \\
GCDFP-15 & Ready to use & 23A3 & Novocastra, New Castle, UK \\
P63 & 1: 25 & 7JUL & Novocastra, New Castle, UK \\
CD30 & Ready to use & JCM182 & Novocastra, New Castle, UK \\
PLAP & Ready to use & 8A9 & Novocastra, New Castle, UK \\
Chromogranin & Ready to use & 5H7 & Novocastra, New Castle, UK \\
CD117 & Ready to use & T595 & Novocastra, New Castle, UK \\
Calretinin & 1:200 & CAL6 & Novocastra, New Castle, UK \\
\hline
\end{tabular}


Table 2 Literature review of clinicopathological data of primary thymic adenocarcinomas

\begin{tabular}{|c|c|c|c|c|c|c|c|c|c|}
\hline Author & Year & Sex & Age & Symptoms & Tumor type & Site & $\mathrm{RX}$ & Outcome & Associated findings \\
\hline Moriyama S [2] & 1989 & F & 51 & Hyperthyroidism & Papillo-tubular & $\begin{array}{l}\text { Right lobe of the } \\
\text { thymus }\end{array}$ & S & No recurrence for 14 years & Multiple thymic cysts \\
\hline Babu MK [19] & 1994 & M & 50 & NA & Conventional & NA & & Alive after 4 months & Congenital thymic cyst \\
\hline \multirow[t]{3}{*}{ Makino Y [6] } & \multirow[t]{3}{*}{1998} & M & 39 & Chest pain & Papillary carcinoma & NA & $S, R$ & Alive after 5 months & NA \\
\hline & & M & 70 & Not mentioned & Papillary carcinoma & Anterior mediastinum & $S, R$ & Recurrence after 8 months & Numerous psammoma bodies \\
\hline & & F & 69 & Not mentioned & Papillary carcinoma & $\begin{array}{l}\text { Left lower pole of the } \\
\text { thymus }\end{array}$ & S & Not mentioned & Thymoma of medullary type \\
\hline \multirow[t]{2}{*}{ Matsuno [5] } & \multirow[t]{2}{*}{1998} & F & 61 & Not mentioned & Papillary carcinoma & $\begin{array}{l}\text { Substernalmediastinal } \\
\text { mass }\end{array}$ & $S, R, C$ & Died after 7 months & $\begin{array}{l}\text { Chronic elephantiasis } \\
\text { nostrasverrucosum in skin }\end{array}$ \\
\hline & & M & 57 & Not mentioned & Papillary carcinoma & Anterior mediastinum & $S, R, C$ & Alive after 5 years & No \\
\hline Shimono [20] & 2001 & M & 61 & facial edema, general fatigue & Not specified & Anterior mediastinum & $S, R, C$ & Alive after 53 months & No \\
\hline \multirow[t]{2}{*}{ Zaitlin [21] } & \multirow[t]{2}{*}{2003} & $\mathrm{~F}$ & 51 & Asymptomatic & Papillary carcinoma & $\begin{array}{l}\text { Anterior left } \\
\text { mediastinum }\end{array}$ & $S, R$ & Died after 26 months & Thymic cyst \\
\hline & & M & 39 & Cough\&lethargy & Papillary carcinoma & Anterior mediastinum & $S, R, C$ & Alive after 3 years & NA \\
\hline Choi WW [7] & 2003 & M & 15 & Dry cough & Mucinous carcinoma & $\begin{array}{l}\text { Right anterior } \\
\text { mediastinum }\end{array}$ & $S, R$ & Died after 26 months & $\begin{array}{l}\text { Thymiccyst\&cribriform, } \\
\text { carcinomatous gland in thymic } \\
\text { medulla }\end{array}$ \\
\hline Misao [10] & 2004 & M & 59 & $\begin{array}{l}\text { Accidental finding in } \\
\text { chest } x \text { ray }\end{array}$ & Not specified & Anterior Mediastinum & $\mathrm{S}, \mathrm{C}$ & Died after 24 months & No \\
\hline Takahashi F [1] & 2004 & M & 49 & $\begin{array}{l}\text { Accidental finding in } \\
\text { chest } x \text { ray }\end{array}$ & Mucinous carcinoma & Anterior mediastinum & $\mathrm{R}$ & Died 11 months after DX & Increased CA19-9, CEA \\
\hline Seki, ErinaMD [11] & 2004 & \multicolumn{2}{|l|}{ M } & Left shoulder pain & $\begin{array}{l}\text { Mucinous adenocarcinoma } \\
\text { with pleural dissemination }\end{array}$ & Anterior mediastinum & R.C & $\begin{array}{l}\text { Alive in } 11 \text { months after } \\
\text { surgery. }\end{array}$ & No \\
\hline Yoshino M [12] & 2005 & $\mathrm{~F}$ & 29 & $\begin{array}{l}\text { Accidental finding in } \\
\text { chest } x \text { ray }\end{array}$ & Papillary carcinoma & Anterior mediastinum & S & Not mentioned & $\begin{array}{l}\text { Type A thymoma, Psammoma } \\
\text { bodies and follicles }\end{array}$ \\
\hline PayalKapur [4] & 2006 & M & 41 & Not mentioned & Mucinous carcinoma & Anterior mediastinum & $R, c$ & 2 recurrence in 3 years & Multiple thymic cysts \\
\hline \multirow[t]{2}{*}{ ToyomitsuSawai [9] } & \multirow[t]{2}{*}{2006} & M & 34 & $\begin{array}{l}\text { Accidental finding in } \\
\text { chest } x \text { ray }\end{array}$ & $\begin{array}{l}\text { Moderately differentiated } \\
\text { adenocarcinoma }\end{array}$ & $\begin{array}{l}\text { Right anterior } \\
\text { mediastinum }\end{array}$ & $R, C$ & $\begin{array}{l}\text { Lung metastasis after eight } \\
\text { months of surgery }\end{array}$ & Increased CA19-9, CEA \\
\hline & & $\mathrm{F}$ & 61 & $\begin{array}{l}\text { Hoarseness, dysphagia, } \\
\text { left shoulder pain, and } \\
\text { fatigue }\end{array}$ & Mucinous carcinoma & $\begin{array}{l}\text { Superoanterior } \\
\text { mediastinum }\end{array}$ & $S, R$ & $\begin{array}{l}\text { Metastatic disease to } \\
\text { retroperitoneal lymph nodes } \\
\text { at } 5 \text { months }\end{array}$ & Psammoma bodies \\
\hline Seong H. Ra [13] & 2007 & $\mathrm{~F}$ & 82 & $\begin{array}{l}\text { Shortness of breath, } \\
\text { chest tightness, back stiffness, } \\
\text { and weight loss of } 15 \mathrm{lb}\end{array}$ & Mucinous carcinoma & Anterior mediastinum & S & $\begin{array}{l}\text { Passed away due to surgical } \\
\text { complications }\end{array}$ & $\begin{array}{l}\text { Thymiccyst, signetringlike } \\
\text { features }\end{array}$ \\
\hline Furtado [14] & 2008 & M & 44 & $\begin{array}{l}\text { Accidental finding in } \\
\text { chest } x \text { ray }\end{array}$ & Papillary carcinoma & Pretracheal region & $S, R, C$ & Alive for 24 months & Psammoma bodies \\
\hline HosakaY [15] & 2009 & M & 36 & $\begin{array}{l}\text { Accidental finding in } \\
\text { chest } x \text { ray }\end{array}$ & $\begin{array}{l}\text { Moderately differentiated } \\
\text { adenocarcinoma with } \\
\text { papillary formation }\end{array}$ & $\begin{array}{l}\text { Right anterior } \\
\text { mediastinum }\end{array}$ & $\mathrm{R}$ & $\begin{array}{l}\text { Alive in } 11 \text { years after } \\
\text { surgery }\end{array}$ & Type AB thymoma \\
\hline
\end{tabular}


Table 2 Literature review of clinicopathological data of primary thymic adenocarcinomas (Continued)

\begin{tabular}{|c|c|c|c|c|c|c|c|c|c|}
\hline \multirow[t]{2}{*}{ Toshiji I [16] } & 2009 & M & 54 & $\begin{array}{l}\text { Cough, fever, dyspnea,chest } \\
\text { pain, facial edema }\end{array}$ & $\begin{array}{l}\text { Poorly differentiated } \\
\text { sarcomatoid tumor } \\
\text { cells partially composed } \\
\text { of papillotubular } \\
\text { adenocarcinoma }\end{array}$ & Anterior mediastinum & R & $\begin{array}{l}\text { Passed away } 56 \text { days } \\
\text { after the initialsymptoms }\end{array}$ & $\begin{array}{l}\text { Slight elevation of sialyl Lewis- } \\
\text { x antigen,soluble interleukin-2 } \\
\text { receptor }\end{array}$ \\
\hline & & $\mathrm{F}$ & 52 & $\begin{array}{l}\text { Bulging of the left } \\
\text { parasternal region }\end{array}$ & Mucinous carcinoma & Anterior mediastinum & $S, R, C$ & $\begin{array}{l}\text { Lung metastasis after } \\
7 \text { months }\end{array}$ & Thymic cyst \\
\hline \multirow[t]{2}{*}{ Maeda D [17] } & 2009 & M & 38 & Chest pain & Mucinous carcinoma & Anterior mediastinum & $S, R, C$ & $\begin{array}{l}\text { Died } 12 \text { months after } \\
\text { diagnosis }\end{array}$ & No \\
\hline & & M & 55 & Chest tightness & Mucinous carcinoma & Anterior mediastinum & $S, R, C$ & $\begin{array}{l}\text { Died } 24 \text { months after } \\
\text { diagnosis }\end{array}$ & No \\
\hline Yong Joon Ra [18] & 2010 & M & 68 & $\begin{array}{l}\text { Dyspnea and chest } \\
\text { pain on left anteriorchest }\end{array}$ & Conventional & Anterior mediastinam & $\begin{array}{l}\text { Not } \\
\text { mentioned }\end{array}$ & Not mentioned & Slightly increased ( $\beta$-hCG) level \\
\hline Current case & 2010 & $\mathrm{~F}$ & 28 & $\begin{array}{l}\text { Neck and right upper } \\
\text { extremity pain and dyspnea }\end{array}$ & Mucinous & Anterior mediastinam & $S, R, C$ & $\begin{array}{l}\text { Two recurrences in two } \\
\text { years follow up }\end{array}$ & $\begin{array}{l}\text { Thymic cyst and psammoma } \\
\text { bodies, increased CA19-9 }\end{array}$ \\
\hline
\end{tabular}

Abbreviations: NA not available, S Surgery, $R$ Radiotherapy, C Chemotherapy, Thy Thymectomy. 
Table 3 Clinicopathologic data of the thymic adenocarcinoma reported in literature according to the four major subtypes

\begin{tabular}{lcccccccc}
\hline $\begin{array}{l}\text { Tumor } \\
\text { subtype }\end{array}$ & $\begin{array}{c}\text { Total } \\
\text { case }\end{array}$ & $\begin{array}{c}\text { Male/ } \\
\text { Female }\end{array}$ & $\begin{array}{c}\text { Median } \\
\text { age }\end{array}$ & $\begin{array}{c}\text { Associated } \\
\text { thymic cyst }\end{array}$ & $\begin{array}{c}\text { Associated } \\
\text { thymoma }\end{array}$ & $\begin{array}{c}\text { Associated } \\
\text { psammoma } \\
\text { body }\end{array}$ & Associated serum tumor markers \\
\hline Papilotubular & 2 & 1 & 52.5 & 1 & 0 & 0 & & B-HCG \\
Conventional & 3 & 3 & 50.6 & 1 & 0 & 0 & 1 & 1 \\
Papillary & 10 & 1.5 & 49.5 & 1 & 3 & 3 & 1 & 1 \\
NOS & 2 & 2 & 60 & 0 & 0 & 0 & 1 & 1 \\
Mucinous & 9 & 2 & 50.2 & 4 & 0 & 1 & 3 & 1 \\
\hline
\end{tabular}

manufacturers. Slides were scanned with the G2565CA Microarray Scanner (Agilent) at a scan resolution of $5 \mu \mathrm{m}$. Signal intensities from the generated images were measured and evaluated with Feature Extraction 10.10.11 and Agilent Genomic Standard Workbench Edition 6.5.0.58 (AGW6.5) software (Agilent) applying the Aberration Detection Method-2 (ADM-2) algorithm with a threshold of 6.0. It showed a complex karyotype with multiple gains and losses. Part of the HLA-DR5 locus in chromosomal region $6 \mathrm{p} 21.32$ seemed to be homozygously deleted (Figure 1I, J).

\section{Consent}

"Written informed consent was obtained from the patient for publication of this case report and any accompanying images. A copy of the written consent is available for review by the Editor-in-Chief of this journal."

\section{Discussion}

Metastatic neoplasms to the mediastinum account for most of epithelial cell neoplasms. The second most common tumors are thymoma and thymic carcinoma. Primary adenocarcinoma is very rare in mediastinum, so before considering this diagnostic entity, most prevalent tumors such as metastatic adenocarcinomas, germ cell tumors and malignant teratomas must be ruled out $[1,3-5,7,8]$. Through clinical history, imaging studies, absence of extramediastinal tumor and histology, we report a case of primary adenocarcinoma with intestinal differentiation of the thymus with mucin production.

Immunostains are an important tool in the study of mediastinal tumors. For instance CD5 is a leukocyte marker expressed on differentiating thymocytes. It is said to be useful in differentiating thymic from nonthymic carcinomas $[4,7,8]$. Caution must be given because CD5 is positive in malignant pleural mesothelioma and adenocarcinomas of other (non thymic origin) organs $[4,8]$. It is also important to exclude tumors derived from the lung and pleura by evaluating TTF-1 and calretinin.
The exact origin of thymic adenocarcinoma is not clear. Glandular differentiation is rarely seen in ultrastructural studies of normal thymic epithelial cells [5]. Also, in the involuted thymus, glandular or tubular structures can be found [7]. Therefore, adenocarcinomas can result from extreme glandular differentiation during tumor progression.

Review of the literature on thymic adenocarcinoma is shown in Tables 2 and 3. Twenty-six cases have been reported. Patients range in age from 15 to 82 years (mean $50 \mathrm{y} \pm 17 \mathrm{y}$ ). Male/female ratio is $1.9 / 1$. The most common morphologic subtypes are papillary carcinoma (38\%), mucinous adenocarcinoma (34\%), conventional adenocarcinoma $(0.11 \%)$, NOS $(0.07 \%)$ and papilotubular carcinoma $(0.07 \%)$. Median age is 52.56 years. Associated findings are thymic cyst in $26 \%$ (mostly seen in mucinous subtype), thymoma in $11 \%$ (only in papillary subtype) and psammoma bodies in 15\% (mostly seen in papillary subtype). Serum tumor markers were increased. CEA in 23\% (mostly seen in mucinous subtype), B-HCG in $0.38 \%$ (only in conventional subtype) and CA19-9 in $11 \%$ (one papillary, one NOS and two mucinous subtypes, including ours). Immunohistochemistry on different subtypes were performed in a limited number of papers and showed positivity in CK7 (7/11), CK20 (6/9), CEA (6/9), Leu M1 (4/5), B-HCG (1/2), CDX-2 (3/4), Muc2 (1/2), Muc5 (2/2), CD5 (8/12), P63 (1/2), CA-19-9 (3/3), CAM5.2 (2/2), CK5,6 (1/2), P53 (2/2), Her2 (1/2) [4-7,9-18].

In our case the adenocarcinoma was associated with a large benign thymic cyst with columnar epithelium. It showed no dysplastic change.

Most of the patients with thymic adenocarcinoma do not have any chief complaint (41\%). In symptomatic group, the most common presenting sign is chest pain $(0.17 \%)$. Other rare signs are cough $(0.05 \%)$, dyspnea $(0.05 \%)$, and shoulder pain $(0.05 \%)$. Weight loss is a rare sign in this tumor $(0.05 \%)$. Anterior mediastinum is the most common location (79\%) followed by right, left, substernal and pretracheal mediastinum (each below\%1). Prognosis cannot be accurately evaluated due to low incidence rate of thymic adenocarcinoma. Some patients 
underwent surgical resection (15 cases), chemotherapy (12 cases) or radiotherapy (19 cases). Clinical outcome showed local recurrences ( 2 cases), metastatic disease ( 3 cases) and death due to surgical complication or disease ( 9 cases). According to Table 3, mucinous has much worse prognosis than papillary carcinoma ( $\mathrm{p}$ value $<0.05$ ). There are diverse genetic heterogenecity in thymic tumors. Genetic characterization has concentrated on WHO types A, B3, and C that harbors few lymphocytes [22]. No chromosomal gain is seen in type $\mathrm{A}$ and $\mathrm{AB}$ thymomas [8]. Simultaneous gain of $1 \mathrm{q}$ and loss of chromosome 6, and 13q aberrations frequently detected in type B3 thymomas. Loss of heterozygosity ( $\mathrm{LOH}$ ) on chromosome 6 is the most frequent genetic abnormality in thymoma. Recent studies on genetic alterations of thymoma based on (LOH) analyses inferred two different genetic pathways of tumorigenesis of thymoma, and heterogeneous genetic alterations in subtypes of thymoma, were identified by CGH and LOH analyses [22,23]. One of the important findings in the thymic epithelial tumor is frequent and multiple genetic aberrations of chromosome 6 that are found in 77.5 percent of them. There are five hotspots of frequent deletions indicating that several putative tumor suppressor genes on chromosome 6 are involved in the development of thymic epithelial tumor $[8,22,23]$. Deletion sites such as $6 \mathrm{q} 21,6 \mathrm{q} 23$, and $6 \mathrm{q} 25-27$ are well established in thymoma. As Zhou et al. reported; the most frequent LOH was found in the 6q23.3-25.3 chromosomal region and the second hot spot of deletions was located in the 6 p21 region containing the major histocompatibility (MHC) classes I and II gene loci [22,24].

In our case, the HLA-DRB5-locus in chromosomal region 6 p21.32 was homozygously deleted, showing similar genetic aberrations with other thymic epithelial tumors.

\section{Conclusion}

This primary adenocarcinoma of the thymus with intestinal differentiation shows homozygous deletion of part of the HLA- locus in chromosomal region 6p21.32 confirmed by CGH array. It is associated with a benign thymic cyst. This is the first genetic study on a primary thymic adenocarcinoma (mucinous type), which shows a similar genetic aberration with other thymic epithelial tumors. We suggest adding genetic study to clinicopathologic and imaging workup for confirmation of diagnosis of a primary thymic tumor.

\section{Competing interests}

No conflict of interest is declared, and source of funding is Dr. Daneshbod Laboratory.

\section{Authors' contributions}

YD, MM, MR and AS were involved in diagnosis, conception, design, acquisition of data, analysis and interpretation of data and were directly involved in drafting and revising the manuscript. IN and RS were participated in the array $\mathrm{CGH}$, analysis and interpretation of data and revising the manuscript. PB reviewed this case and confirmed the diagnosis as well as extensively revised the paper. All authors read and approved the final manuscript.

\section{Acknowledgements}

We like to thank Professor K. Daneshbod for his scientific comments and guidance and Mrs. F. Hadad, for performing immunohistochemicalstainings.

\section{Author details}

${ }^{1}$ Department of Molecular Pathology, Dr Daneshbod Pathology Laboratory, Shiraz, Iran. ${ }^{2}$ Department of Hematology- Oncology, Shiraz University of Medical Sciences, Shiraz, Iran. ${ }^{3}$ Institute of Human Genetics,

Christian-Albrechts University Kiel and University Hospital Schleswig-Holstein, Campus Kiel, Kiel, Germany. ${ }^{4}$ Department of Pathology, JMH/University of Miami School of Medicine, Miami, USA.

Received: 2 January 2013 Accepted: 22 May 2013

Published: 31 May 2013

\section{References}

1. Takahashi F, Tsuta K, Matsuno Y, Takahashi K, Toba M, Sato K, Uekusa T, Izumi H, Nakamura K, Hirose S, Fukuchi Y: Adenocarcinoma of the thymus: mucinous subtype. Hum Pathol 2005, 36:219-223.

2. Moriyama S, Shimizu N, Kurita A, Teramoto S, Taguchi K: A case of adenocarcinoma of the thymus. Nihon KyobuGekaGakkaiZasshi 1989, 37:717-722

3. Shimosato $Y$, Mukai K: Tumors of the mediastinum. Atlas of tumor pathology, third series, fascicle 21. Washington, DC: Armed Forces Institute of Pathology; 1997:120-158.

4. Kapur P, Rakheja D, Bastasch M, Molberg KH, Sarode VR: Primary mucinous adenocarcinoma of the thymus: a case report and review of the literature. Arch Pathol Lab Med 2006, 130:201-204.

5. Matsuno Y, Morozumi N, Hirohashi S, Shimosato Y, Rosai J: Papillary carcinoma of the thymus: report of four cases of a new microscopic type of thymic carcinoma. Am J SurgPathol 1998, 22:873-880.

6. Makino Y, Asada M, Suzuki T, Hashimoto M: A case of adenocarcinoma of the thymus. Jpn J Thorac CardiovasC Surg 1998, 46:1168-1171.

7. Choi WW, Lui YH, Lau WH, Crowley P, Khan A, Chan JK: Adenocarcinoma of the thymus: report of two cases, including a previously undescribed mucinous subtype. Am J Surg Pathol 2003, 27:124-130.

8. Shimosato Y, Mukai K: Tumors of the mediastinum. Atlas of tumor pathology, forth series, fascicle 11. American Registry of Pathology: Washington, DC; 2010.

9. Sawai T, Inoue $Y$, Doi S, Ikuta Y, Kimino K, Nakashima M, Soda H, Kohno S: Tubular adenocarcinoma of the thymus: case report and review of the Literature. Int J Surg Pathol 2006, 14:243-246.

10. Misao T, Yamamoto Y, Nakano H, Toyooka S, Yamane M, Satoh K: Primary thymic adenocarcinoma with production of carbohydrate antigen 19-9 and carcinoembryonic antigen. Jpn J ThoracCardiovascSurg 2004, 52:30-32.

11. Seki E, Aoyama K, Ueda M, Haga T, Nakazato Y, lijima M, Kojima M, Tanaka R: Mucinous adenocarcinoma of the thymus: a case report. J Thorac Oncol 2008, 3:935-937.

12. Yoshino M, Hiroshima K, Motohashi S, Shibuya K, lyoda A, Sekine Y, Fujisawa T: Papillary carcinoma of the thymus gland. Ann Thorac Surg 2005, 80:741-742.

13. Ra SH, Fishbein MC, Baruch-Oren T, Shintaku P, Apple SK, Cameron RB, Lai CK: Mucinous adenocarcinomas of the thymus: report of 2 cases and review of the literature. Am J Surg Pathol 2007, 31:1330-1336.

14. Furtado A, Nogueira R, Ferreira D, Tente D, Eisele R, Parente B: Papillary adenocarcinoma of the thymus: case report and review of the literature. Int J Surg Pathol 2010, 18:530-533.

15. Hosaka Y, Tsuchida M, Umezu H, Eimoto T, Hashimoto T, Shinohara H, Hayashi J: Primary thymic adenocarcinoma coexisting with type $A B$ thymoma: a rare case with long-term survival. Gen Thorac Cardiovasc Surg 2010, 58:488-491.

16. Toshiji I, Mitsuaki S, Tsutomu S, Takashi M, Toshio K, Kazuhisa T: Thymic adenocarcinoma with sarcomatoid features characterized bylntracaval tumor growth: report of a case. Surg Today 2010, 40:1068-1072.

17. Maeda D, Ota S, Ikeda S, Kawano R, Hata E, Nakajima J: Mucinous adenocarcinoma of the thymus: a distinct variant of thymic carcinoma. Lung Cancer 2009, 64:22-27. 
18. Ra YJ, Bae MJ, Kim YS, Choi KU: Difficulties in diagnosis and treatment of thymic adenocarcinoma producing $\beta$-human chorionic gonadotropin in anterior mediastinum. Interact Cardiovasc Thorac Surg 2010, 11:114-116.

19. Babu MK, Nirmala V: Thymic carcinoma with glandular differentiation arising in a congenital thymiccyst. J Surg Oncol 1994, 57:277-279.

20. Shimono M, Hiraki A, Ueoka H, Tanimoto Y, Aoe M, Sakae K, Kaneda K, Sakugawa M, Kiura K, Harada M: Successful treatment with concurrent chemoradiotherapy followed by surgery for a patient with thymic adenocarcinoma. Anticancer Res 2001, 21:2519-2522.

21. Zaitlin N, Rozenman J, Yellin A: Papillary adenocarcinoma in athymic cyst: a pitfall of thoracoscopic excision. Ann Thorac Surg 2003, 76:1279-1281.

22. Lee GY, Yang WI, Jeung HC, Kim SC, Seo MY, Park CH, Chung HC, Rha SY: Genome-wide genetic aberrations of thymoma using CDNA microarray based comparative genomic hybridization. BMC Genomics 2007, 8:305.

23. Inoue M, Starostik P, Zettl A, Ströbel P, Schwarz S, Scaravilli F, Henry K, Willcox N, MüllerHermelink H-K, Marx A: Correlating genetic aberrations with world health organization defined histology and stage across the spectrum of thymomas. Cancer Res 2003, 63:3708-3715.

24. Zhou R, Zettl A, Ströbel P. Wagner K, Müller-Hermelink HK, Zhang SSJ, Marx A, Starostik P: Thymic epithelial tumors can develop along two different pathogenetic pathways. Am J Pathol 2001, 159:1853-1860.

doi:10.1186/1472-6890-13-17

Cite this article as: Maghbool et al:: Primary adenocarcinoma of the thymus: an immunohistochemical and molecular study with review of the literature. BMC Clinical Pathology 2013 13:17.

\section{Submit your next manuscript to BioMed Central and take full advantage of:}

- Convenient online submission

- Thorough peer review

- No space constraints or color figure charges

- Immediate publication on acceptance

- Inclusion in PubMed, CAS, Scopus and Google Scholar

- Research which is freely available for redistribution 